\title{
More Good Times and Hard Times: Family Diversity in a Rural Michigan Community
}

\author{
Barbara Wells ${ }^{1}$
}

\begin{abstract}
This article presents the results of a 2002 follow-up study to a 1995-96 case study of rural families in a small Michigan community. The initial research found family experience to vary broadly by social-class location. The new research finds that the circumstances of middle-class families have remained stable, while working-class and poor families have been susceptible to family instability and job loss. A central concern for most women interviewed continues to be the difficulty of earning a "decent living" in a low-wage labor market.
\end{abstract}

Key Words: Rural families, social class, marriage, work, family diversity, social policy

${ }^{1}$ Barbara Wells, Ph.D., is Associate Professor, Department of Sociology, 213 A Thaw Hall, Maryville College, Maryville, TN 37804-5907. Electronic mail may be sent via the Internet to barbara.wells@maryvillecollege.edu

$\mathbf{R}_{\text {ural America is widely assumed to be a positive and wholesome }}$ environment for families. The experiences of the women studied here do not uniformly fit that optimistic construction. This study joins a significant literature that challenges the idealization of rural family life (e.g., Bokemeier \& Garkovich, 1991; Egan, 2002; Gringeri, 2001; Willits \& Luloff, 1995). This article presents the results of a follow-up study to a 1995-1996 case study of White rural families in a small Michigan community. In the summer of 2002, I returned to the research community to interview a subgroup of women who had participated in the initial study. In this paper, I summarize the results of the initial study and present key findings from the new research ${ }^{1}$.

${ }^{1}$ The initial research was supported in part by the Michigan Agricultural Experiment Station (Project \#3337). The follow-up research was supported by a John B. Stephenson Research Fellowship from the Appalachian College Association. 
The central concerns of the initial study were family structure, economic subsistence, and difference. I explored family structure by asking: How are the family households in this sample configured? Are current household arrangements longstanding or are they characterized by substantial fluidity? I addressed economic subsistence by asking: What decisions do family members make and what actions do they take to sustain their households economically? I examined difference in the experience of rural families by analyzing them through the lens of social class, asking: How does family experience vary by social class? How do the ways that families are structured and sustain themselves economically differ by social class?

Diversity is doubtlessly a hallmark of contemporary family life. Family scholars recognize that race, class, and gender create a multiplicity of social locations from which individuals create and maintain their family lives. Among this sample of White women, diversity in family experience appeared along the lines of social class. Both family structure variation and differentiation in patterns of resource generation were associated with the social-class position of families. Middle-class families had secure economic resources and stable family circumstances. Moving down the social-class ladder, I found increasingly insecure economic resources and unstable family circumstances. Research participants in higher social-class locations generally described their family lives in terms of "good times" while individuals in lower social-class locations were more likely to describe "hard times." The follow-up study finds that patterns identified in the initial research generally continued in the years between the initial and subsequent studies.

A substantial body of literature documents how macrostructural changes in recent decades have created diverse and challenging economic contexts for constructing and maintaining family life (e.g., Edin \& Lein, 1996; Nelson \& Smith, 1999; Rubin, 1994; Stacey, 1990; Wilson, 1987). This literature illumines the interrelationship between households and the communities in which they are situated. The salient point for this research is that individuals make family-related decisions (for instance, when and whether to marry or divorce) and strategies for making ends meet (for instance, when and whether a primary breadwinner moonlights or a mother takes a job) in specific social and economic contexts.

I studied a sample of families in a rural setting to explore how this unique social and economic context shapes family outcomes that may be particular to this situation. While space limitations here preclude a wide-ranging discussion of either rural family demographics or labor markets, two general points are particularly relevant to this analysis. First, rural workers encounter a more restrictive set of employment opportunities than do urban workers. Rural 
labor markets tend to offer low-skill, low-wage work that is frequently part-time or seasonal (Gibbs, 2001). Per capita income in rural areas is approximately 70 percent of income in urban areas (Economic Research Service [ERS], 2003). Second, while the percentage of nonfamily households and female-headed family households continues to rise in all spatial contexts, nonetheless rural residents continue to be more likely to live in married couple households than are their urban counterparts. Census 2000 found that the percentage of married couple households (among households of all types) was 50.7 percent for metro areas and 55.4 percent for nonmetro areas (U.S. Census, 2001).

The theoretical and conceptual framework undergirding this article is thoroughly feminist. First, the work is grounded in the feminist assumption that women's lives are important (Reinharz, 1992). One of the goals of feminist scholarship is to redress the historic invisibility of women and their experiences that has characterized traditional scholarship. Specifically relevant to the concerns of this research is the observation that women's perspectives have been largely missing from analyses of rural places and women's economic concerns have been mostly ignored in rural social policy. Historically, economic issues in rural areas have been addressed through rural development policy (Buttel et al., 1993). Such policies have advanced male-dominated economic activities, while little attention has been given to how these initiatives affect rural families and women (Tickamyer et al., 1993). My analysis focuses on the experiences and viewpoints of women because they are well situated to provide knowledge that clarifies the interrelationship of the local community context and family life.

Second, this paper's analytic strategy reflects feminist understandings about the social forces that produce and sustain family variation. One of the central contributions of feminist family scholars has been in uncovering family diversity and theorizing about it (White \& Klein, 2002). My work is dependent on the insights of scholars who show how family experience is shaped by larger structures of inequality that provide varying patterns of opportunities and constraints to families positioned differently in society (e.g., Catanzarite \& Ortiz, 1996; Rapp, 1992, 1978; Thorne, 1992). Rural sociologist Cornelia Flora identified an ideology of "we're all just folks" that obscures social class differences in rural areas (Flora, 1992, p. 202). That ideology notwithstanding, I expect patterns of stability and fluidity in family structure and economic resources to continue to follow social-class lines.

\section{Research Setting and Method}

The initial research was a case study that explored stability and change in the lives of a sample of 30 White families with young children in a rural 
Michigan community (Wells, 1999, 2002). ${ }^{2}$ All research participants were parents of a second- or third-grade student in a small rural school district with a population of approximately 7,000. The data used are drawn from semistructured, face-to-face interviews and self-administered pre-interview surveys. Families were divided into social-class categories based on the characteristics of family members' employment (following Collins, 1998; Wright, Hachen, Costello, \& Sprague, 1982; and others). Middle-class families are those in which one earner-either male or female-is employed full-time as an administrator, professional, or manager (Higginbotham \& Weber, 1992). Families of lower than middle-class status were divided into working class and the poor. On this basis, four sample families were categorized as middle class, seventeen as working class, and nine as poor. Because family income in the working class varied widely, I divided the working class into two subgroups: a higher-income subgroup of seven families with incomes above $\$ 30,000$ and a lower-income subgroup of ten families with incomes below $\$ 30,000$, but above the poverty threshold. ${ }^{3}$

The small school district in which the research was set is situated in an economically depressed nonmetropolitan Michigan county. ${ }^{4}$ The county population is predominately White $(96 \%)$ and nonfarm $(97 \%)$. This county offers limited economic opportunity for its residents, with employment strongly oriented toward low-wage service jobs. The county's poverty rate was 17.5 percent in 1995. Between 1995 and 2000, poverty and unemployment declined in both the research county and the state of Michigan, and then increased significantly between 2000 and 2002. In 2002, the poverty rate was back up to nearly 17 percent. The research setting is a 40- to 50-mile drive from a metropolitan area.

In the summer of 2002, I returned to the research setting to locate and interview some of the original research participants and explore recent developments in the community. Adding a longitudinal research component to

\footnotetext{
${ }^{2}$ An extensive discussion of methodological and analytical matters related to the initial research can be found in Wells, 1999.

${ }^{3}$ In this research, I consider families whose income is less than 1.25 of the official poverty threshold to be poor. Many scholars believe that official poverty thresholds are set too low, underestimating poor families' needs by around 25 percent (Jencks, 1997).

${ }^{4}$ A condition for community cooperation in this research was that the community not be identified. County-level and community-level social and economic data used in this paper are drawn from ERS/USDA, State of Michigan and U.S. Census Bureau websites, and Gaguin and DeBrandt (2000).
} 
the initial study allowed me to reassess patterns identified earlier in class-based groups of families. I was able to gather some information on all of the original 30 families and eventually found that 27 of the families remained in the locale. I interviewed 13 women who had participated in the original research. I selected a multi-class sample that included women whose households were structured in various ways (married couple, single mother, cohabiting) and had diverse patterns of resource generation. I interviewed two of four $(50 \%)$ of the original middle-class participants; seven of seventeen (41\%) working-class participants, and four of nine (44\%) interviewees who had been poor.

\section{Stability and Change in Family Structure}

In the initial research, I examined the family structure realities of the families represented in this research by analyzing three indicators of family stability: marital status, marital history, and household composition. The marital status breakdown of the families was as follows: 77 percent $(n=23)$ of sample family households were married couple families, 10 percent $(n=3)$ were separated, 10 percent $(n=3)$ were divorced, and 3 percent $(n=1)$ were widowed. These percentages approximate the marital status groups in the research county and in nonmetropolitan areas of the U.S.

Marital status is frequently used as an indicator of family stability, that is, children who live in married-couple households are assumed to live in stable nuclear families. I found, however, that including marital history and household compositional data uncovered considerable complexity and instability in the lives of many children living in married-couple families. Among married-couple households, 15 were households formed by an interviewee's first marriage and 8 were remarriages. In addition, because the family histories of couples in first marriages were sometimes complicated, I made a distinction between conventional first marriages and unconventional first marriages. Eleven of fifteen couples had conventional first marriages, that is, marriages that conformed to the social convention that couples marry prior to (or close to) the birth of their first child. (For examples of unconventional first marriages, see the accounts of the Edwards and Patterson families on pp. 13-14.)

I found that the likelihood that children lived in stable nuclear families was clearly associated with social-class placement. All middle-class couples were in conventional first marriages; a total of 7 of 17 working-class households (41\%) consist of couples with conventional first marriages (of these, four were in the higher-income subgroup, while three were in the lower-income subgroup); no poor households had conventional first marriages. Similarly, the likelihood that children lived in households with both their parents was also associated with 
social-class position. Here the experience of poor children differed dramatically from that of middle-class and working-class children. While all middle-class children and 65 percent of working-class children lived with both parents, only 22 percent ( 2 out of 9 ) poor children lived with both parents. These relationships are captured in Table 1. In the column labeled "Marital history/current relationship in 1995/96," "lst" means that that a family consists of a couple in a conventional first marriage, that is, families who typify the traditional nuclear form. The "Number of child's parents in household" column indicates whether a child lives in a household with one or both of his or her parents.

Table 1: Characteristics of Class-Based Groups of Sample Families $(n=30)$

\begin{tabular}{|c|c|c|c|}
\hline FAMILY & $\begin{array}{l}\text { NUMBER OF } \\
\text { CHILD'S PARENTS } \\
\text { IN HOUSEHOLD }\end{array}$ & $\begin{array}{c}\text { MARITAL HISTORYI } \\
\text { HOUSEHOLD COMPOSITION IN } \\
1995 / 1996\end{array}$ & $\begin{array}{c}\text { MARITAL HISTORYI } \\
\text { HOUSEHOLD COMPOSITION } \\
\text { KNOWN CHANGES IN } 2002\end{array}$ \\
\hline \multicolumn{4}{|c|}{ Middle Class $(n=4)$} \\
\hline $\begin{array}{l}\text { Cole } \\
\text { Kennedy } \\
\text { Williams } \\
\text { Schram }\end{array}$ & $\begin{array}{l}\mathbf{2} \\
\mathbf{2} \\
2 \\
2 \\
\end{array}$ & $\begin{array}{l}1^{\text {st }} \\
1^{\text {st }} \\
1^{\text {st }} \\
1^{\text {st }}\end{array}$ & \\
\hline \multicolumn{4}{|c|}{ Working Class $(n=17)$} \\
\hline $\begin{array}{l}\text { Nichols } \\
\text { Molloy } \\
\text { Olsen } \\
\text { Collins } \\
\text { Mannelli } \\
\text { Walsh } \\
\text { Davis }\end{array}$ & $\begin{array}{l}1 \\
2 \\
1 \\
\mathbf{2} \\
\mathbf{2} \\
2 \\
2\end{array}$ & $\begin{array}{l}2^{\text {nd }} \\
1^{\text {st }} \\
2^{\text {nd }} \\
1^{\text {st }} \\
2^{\text {nd }} \\
1^{\text {st }} \\
1^{\text {st }}\end{array}$ & Divorced and remarried \\
\hline \multicolumn{4}{|c|}{ Lower Income Subgroup [Income $<\$ 30,000](n=10)$} \\
\hline $\begin{array}{l}\text { Rogers } \\
\text { Griffin } \\
\text { Davenport } \\
\text { Phillips } \\
\text { VanDyke } \\
\text { Edwards } \\
\text { Cooper } \\
\text { Shoemaker } \\
\text { Norris } \\
\text { McCullen }\end{array}$ & $\begin{array}{l}\mathbf{2} \\
2 \\
\mathbf{2} \\
1 \\
\mathbf{2} \\
2 \\
2 \\
2 \\
1 \\
1\end{array}$ & $\begin{array}{l}1^{\text {st }} \\
2^{\text {nd }} \\
1^{\text {st }} \text { (Unconventional) } \\
\text { Separated/cohabiting } \\
1^{\text {st }} \\
1^{\text {st }} \\
1^{\text {st }} \\
2^{\text {nd }} \\
2^{\text {nd }} \\
\text { Divorced }\end{array}$ & $\begin{array}{l}\text { Divorced } \\
\text { Divorced and cohabiting }\end{array}$ \\
\hline \multicolumn{4}{|l|}{ Poor $(n=9)$} \\
\hline $\begin{array}{l}\text { Patterson } \\
\text { Newman } \\
\text { Smith } \\
\text { Roberts } \\
\text { Watson } \\
\text { Miller } \\
\text { Campbell } \\
\text { Morgan } \\
\text { Turner }\end{array}$ & $\begin{array}{l}1 \\
1 \\
1 \\
2 \\
1 \\
1 \\
1 \\
1 \\
2 \\
1 \\
1\end{array}$ & $\begin{array}{l}1^{\text {st }}(\text { Unconventional }) \\
2^{\text {nd }} \\
1^{\text {st }}(\text { Unconventional }) \\
\text { Widowed } \\
\text { Divorced } \\
\text { Divorced/cohabiting } \\
2^{\text {nd }} \\
\text { Separated } \\
\text { Separated }\end{array}$ & $\begin{array}{l}\text { Divorced } \\
\text { Separated } \\
\text { Cohabiting } \\
\text { New cohabiting partner } \\
\text { Divorced } \\
\text { Divorced }\end{array}$ \\
\hline
\end{tabular}

Note: Entries in bold indicate families participating in 2002.

Michigan Family Review, 10, 7-26, 2005 (c) Michigan Council on Family Relations 
In returning to the research community, I found that patterns of family stability and fluidity identified earlier continue to the present. Table 1 also shows known changes in marital status and household composition as identified by research participants and others in the follow-up research. To summarize, six sample households experienced divorce in the years between 1995 and 2002. In two of these instances, women who were already separated in 1995 are now divorced. An additional interviewee who was married in 1995, is separated and plans to divorce. Transitions to and between cohabiting relationships are also indicated.

Marital instability continues to be concentrated among lower-income households. All middle-class marriages remain intact, while partners in one upper-income working-class family (Collins) divorced. Two couples in the lower-income subgroup of the working class (Edwards, Shoemaker) have divorced, and three poor households (Patterson, Morgan, Turner) have experienced divorce. In the paragraphs that follow, I describe the circumstances of sample families known to have had marital disruptions or changes in household structure. All names used in this paper are pseudonyms.

Virginia Collins and her husband Patrick divorced in 1996. When interviewed in 1995, Virginia was driving a school bus and Patrick worked in auto body repair. Although many women find that downward social mobility follows divorce, Virginia's experience has been different. She is remarried to a local high school teacher and describes her family's financial situation as much better than at the time of the first interview. Virginia says flatly, "I got rid of the baggage that was holding me down." Their five-person household consists of Virginia, husband Nick, and Virginia's three children from her first marriage.

Tim and Sharon Edwards had been married for four years when interviewed in 1995. After a long-term cohabiting relationship in which two children were born, they married when their children were ages 2 and 5. This couple has divorced and left the area.

Irene Shoemaker's family circumstances have been complicated for many years. Eleven years prior to the first interview, Irene and her first husband divorced, leaving her with three children. The divorce was followed two years later by the nonmarital birth of a daughter, Katie. Irene married Katie's father, Bill, approximately two years later. At the time of the follow-up interview, Irene and Bill had been divorced for two years. Irene lives in the same small home as she did previously; other household members are Katie as well as Irene's cohabiting "fiancé." 
Changes in marital status and household composition are concentrated among households that were poor at the time of the initial research. Two-thirds of poor households (6 out of 9) experienced changed circumstances between 19951996 and 2002. Lynn and Joe Patterson are an example of a household with a complex family history at the time of the first interview. Lynn was a homemaker mother who had three nonmarital births (the three children have different fathers) and then married the father of her youngest child. The couple had been married a year and a half when first interviewed. In 2002, I found their mobile home abandoned. I later learned that the Pattersons had divorced, but that Lynn and the children still lived in the area.

Patty Newman was a mother of four who had been remarried for two and a half years at the time of the initial interview. She had been a divorced mother of three sons who then had a nonmarital birth, and later married Kevin Newman (not the father of her young daughter). Patty says that she "put up" with Kevin for seven and a half years. After that, she could no longer manage his moods, temper, and drinking. She described how he would come home drunk at 2 or 3 a.m. and wake her up "screaming at the top of his lungs," wanting to argue and fight. He had been arrested and jailed for domestic violence. Patty plans to divorce Kevin, but the legal action will be delayed until she (currently unemployed) accumulates $\$ 1,500$ for a lawyer.

Colleen Watson was a divorced mother of two with a hair styling business in her home at the time of the initial interview. At that point she was reflective and somewhat bitter about the unanticipated turn her life had taken as her ex-husband Matt's alcoholism eventually led to divorce. She explained that her ex-husband declared bankruptcy soon after the initial interview and as a result she took a "big financial hit." She and her cohabiting partner, Sid, keep their "financial stuff" separate, but Colleen (still a cosmetologist) says that now, "I have something to fall back on." She is relieved to know that Sid will help her out financially if she needs it.

Robin Miller was a divorced mother of two sons who lived with her cohabiting partner, Tony, and his two daughters in 1995. Economic strain and negotiating a crowded mobile home presented real challenges to Robin at that time. Tony and his children moved out in 1998; in 2001, Robin's current partner, Keith, moved in along with his son and daughter. Robin has a better job than in 1995 and has at long last achieved economic self-sufficiency. She says, "I didn't need to have Keith in the picture. I was doing just fine by myself. But it is nice to have someone to share it with." 
Finally, both Bonnie Morgan and Dorothy Turner were separated from their husbands when they were interviewed in 1995 and 1996. Their economic circumstances were dire at that time. Bonnie Morgan is now divorced and continues to live in the community. Dorothy Turner is also divorced, but she has moved back to her home state of Wisconsin.

The new data showing considerable family instability in the household arrangements of families who were poor in the initial research does not represent the disruption of formerly stable family lives (as was the case with the Collins family). Rather, patterns of family fluidity and change already in place among the more economically disadvantaged households in this sample have continued since the original study. Thus, the family changes documented among poor families were found in households in which children's parents were already separated or divorced in 1995-96. In several cases children who had already experienced the separation and divorce of their parents are confronted with additional changes when remarriages are disrupted or cohabiting partners come (and sometimes go).

One of the conclusions I drew in the original study was that marriage continued to figure very prominently in the experience of sample families. All sample women were either currently or previously married. By the mid-1990s, the first marriages of over a third of these women $(38 \%$, or 11 of 29$)$ had ended in divorce, but nearly three-quarters of divorced women had remarried. In 2002, the situation appears to be different. While many marriage relationships continued to be fragile, women who entered new relationships have been more likely to cohabit than to remarry. While generalizations cannot be made on the basis of this small study, the results found here are consistent with the rapid rise in cohabitation in the U.S. in recent years.

\section{Surviving and Thriving Economically}

In returning to the community, I was interested in assessing how families were faring economically. I approached this question by analyzing employment changes in the years since the mid-1990s. Interviewees were asked whether they or their partners (if applicable) had changed jobs, and if so, why they had changed jobs. In addition, I asked about their perceptions of the economic climate in the community, including local wage scales and the propensity of residents to commute to the metro center for employment. Discussion around these questions was very fruitful because it illumined: first, what these individuals believed their employment options to be in a particular local labor market; and second, what employment-related choices they had made in that context. 
The initial research found a sample of families strongly committed to the ideal of economic self-sufficiency. All households, from middle class to poor, had a household member in the labor force, that is, someone was employed or looking for work. The principal employment-related strategies identified by research participants were commuting to an urban center (53\% of households), dual earning ( $43 \%$ of households), and working overtime (33\% of households). The high rate of commuting reflects the limitations of the local labor market. While middle-class workers generally had local jobs, individuals with workingclass credentials encountered a limited range of employment options and low pay. Commuting usually meant leaving the local nonmetropolitan county, driving through part of another nonmetro county to a metro county-a round-trip commute of between 80 and 120 miles.

In describing the contours of the local economy, several interviewees mentioned businesses that had "gone under" since 1995. Several women expressed regret that Quality Farm and Fleet had closed. Other businesses mentioned as closed were a plastics manufacturing plant, a factory producing shoes, a gas station, and three restaurants. Still other businesses were reported to be "hanging on by a thread."

Considerable change had occurred in the employment circumstances of many sample families. I do not mean to imply in this analysis that employment stability is always positive. Continuing employment in a "good job" may indeed be positive, but continuing in a dead-end job that provides inadequate support for one's family may be negative. Likewise, changing employment may bring more or less income into the household economy.

I discuss employment stability and change by beginning with the experience of middle-class interviewees and then considering the experience of the working class and finally the poor. The experience of the middle class would be expected to be more stable than that of other social classes because administrative, professional, and managerial work is generally more secure than is the typical working-class job. This analysis uses the social-class categories that fit the experience of these families at the time of the initial research. ${ }^{5}$

\footnotetext{
${ }^{5}$ In fact, some families would be categorized differently as to social-class category in the later research. The most noteworthy change is for Virginia Collins who divorced a man with working class employment and married a man with a middle class job. In most cases, changes would reflect whether working poor families raised their income enough to situate their families above the poverty line.
} 
Both middle-class women I interviewed (Kennedy, Cole) indicated that their households have fared well economically in the years since the initial research. Anne Kennedy continues as a teacher while her husband Roger, formerly a journeyman carpenter, has taken a better job as a construction manager for a large contracting company in the county seat. In the years subsequent to the first interview, they have built a lovely new home. Steven Cole continues in his position as a professor at the nearly regional university. Nancy, a registered dietician, decided to make a career change and has just received a Master's Degree in Information Systems Management.

In the prior research, Virginia and Patrick Collins and Rita and Leonard Mannelli were in the higher-income segment of the working class. Virginia, divorced in 1996, is remarried to a local teacher whose employment status is stable. Leonard Mannelli continues to commute to the metro center for his work as a printer. Rita explains that local jobs do not really pay enough to support a family. The way Rita sees it, "People with motivation will drive to [metro center]." Although his daily commute is 100 miles (round-trip), Rita says, "Leonard can't even think about getting a job in this area." Leonard works substantial overtime, putting in an average of 50 hours a week.

The employment experience of the Rogers, VanDyke, Davenport, Shoemaker, and Norris families, all represented in the lower-income subgroup of the working class, has been less stable than that of the families discussed above. Two families, the Rogers and VanDykes, have been hard hit by the loss of male breadwinner jobs. Both Shirley and Brian Rogers had factory jobs when Shirley was interviewed in 1995. After a number of job changes, they had managed to get jobs at the two highest paying manufacturing facilities in the county. Then in 1996, Brian suffered a debilitating back injury and has not worked since then. Shirley's new responsibility as Brian's caregiver forced her to leave her inflexible factory job (paying $\$ 12.75 / \mathrm{hr}$ ). Since then she worked at a grocery store (paying $\$ 5.25 / \mathrm{hr})$ and then a local party store $(\$ 7.25 / \mathrm{hr})$. As she explains, "Things were tough," so she has taken a job as a food service worker with a union employer at a regional university 50 miles away. The good pay and excellent benefits provided by this job have stabilized their economic circumstances, but the future is unclear.

Ruthann VanDyke describes hard times since her husband, Allen, was laid off as a machinist at a metro center factory two years ago. His unemployment compensation has run out and difficult financial circumstances have "put a lot of stress on the family." Allen continues to look for a job in the metro center. Ruthann reports that while some new businesses have come into the county, these employers are paying prevailing low wage rates. Local men 
will take jobs for $\$ 5.15-\$ 7.00$ an hour. She concludes that more people are driving to the metro center to look for jobs with decent pay (defined by Ruthann as $\$ 10.00$ an hour or more) and benefits.

The economic circumstances of Martin and Nicole Davenport have improved since Nicole's first interview. At that point, Nicole had been the family's primary breadwinner for several years, commuting to a metro center factory job while Martin worked in the informal economy cutting and selling firewood. Shortly thereafter, Martin was hired by the same factory. In 1999, Nicole quit her factory job to work part-time as a housekeeper at the Super 8 in the county seat, earning $\$ 5.25$ an hour. She became head housekeeper, earning $\$ 7.25$ and eventually $\$ 8.60$ an hour. Nicole enjoyed the reprieve from commuting, saying, "I got to know my kids a little." Circumstances pushed her back to her old factory job three months before our interview when Martin lost his driver's license and needed transportation to work.

Both Irene Shoemaker and Diane Norris have experienced several employment changes since their interviews in 1995. Irene (who was divorced two years prior to the recent interview) has had two jobs in hotel housekeeping, a job as an assistant manager of a local motel, a grocery store job, and, currently, a job as a home health care provider. Diane, a grill cook, whose husband Ray has had a steady job with a trenching company in the metro center, has had six employers since 1995, along with two job-related injuries, and a period of unemployment. After 22 years in the restaurant business, Diane earns $\$ 7.25$ an hour. Diane is negative about the local economic climate; in short, she says, "It stinks." When asked to describe local job opportunities, she responded, "There are no job opportunities here."

In general, I found that employment circumstances have been unstable for families who were poor at the time of the initial research. In only one of four households does a worker continue in the same job he or she had in 1995, and that worker is self-employed (Watson). Nonetheless, two of the three remaining households (Campbell, Miller) improved their economic circumstances when a worker got a better job or moved from informal to formal employment. The single mother who heads the remaining household (Newman) is currently unemployed.

Colleen Watson continues to operate a hair styling business out of her home. Her customers are mostly "regulars" -individuals who have been coming to her for hair care for many years. Her stable customer base has given her a broad view into the financial circumstances of many community residents. Many of her customers are economically needy. Sometimes she gives free haircuts to 
customers who are going for job interviews. According to Colleen, the biggest issue is the low wage scale for unskilled labor. Many community residents need to work multiple jobs to make ends meet.

At the time of the first interview, the Campbells had endured several years of financial hard times. George had started a lawn mowing business that did not generate adequate income; he was commuting to the metro center to work as a seasonal postal worker when Kimberly Sue was interviewed in 1995. I found that George had been hired in the service department of a metro center auto dealership in 2000. As Kimberly Sue explains, he "knows cars," but is not a certified mechanic. The Campbells cannot afford the health insurance coverage offered through George's employer, but their two daughters are eligible for Medicaid coverage.

When I interviewed Robin Miller in 1995, in the aftermath of divorcing an abusive husband, she was struggling to support herself and her sons on earnings of $\$ 6.00$ an hour at a bank in the county seat. Now Robin earns $\$ 14.00$ an hour in a union job as a bus driver for a nearby school system.

When initially interviewed, Patty Newman was a homemaker, and her husband Kevin was working in a local factory earning $\$ 6.00$ an hour. Shortly thereafter, Patty got a job doing housekeeping in a local nursing home for $\$ 6.47$ an hour. She lost that job and opened a licensed daycare center the following year. Her license was revoked the next year because of an incident related to her husband's drinking. She spent the next three years working full-time as a bartender at the American Legion Hall. In 2001 she took a part-time retail job for $\$ 5.50$ an hour, but left that job due to transportation difficulties and family necessities.

At the time of the initial research, many interviewees hoped that new employers coming into the county would offer better wages that would eventually function to raise the wage structure in the local labor market. This has not occurred. Commuting seems as necessary as ever for individuals with working-class employment. Leonard Mannelli, a printer, commutes for relatively highly paid specialized work that is not available in the community. Others, such as Shirley Rogers, a food service worker, Martin Davenport, a factory worker, and Ray Norris, a trencher, commute to find less specialized working-class employment at higher pay than would be the standard in their residential community. George Campbell commutes to a low-wage job because he had not been able to find any job at all locally. 
The extent to which families participating in this research have opted out of jobs with private employers is noteworthy. Among all follow-up study interviewees and their partners, only Roger Kennedy (a project manager for a building contractor), works for a private-sector employer within the county. Others with private-sector employment drive 15 to 20 miles to jobs in other nonmetro counties, or, far more likely, drive around 50 miles to metro center work places. Interviewees described exiting local clerical, retail, food service, and motel jobs for economic and various personal reasons. Replacement jobs took them either out of the county or out of the private sector. The two individuals who made the greatest steps toward providing a secure income for their families are Robin Miller and Shirley Rogers, both of whom have secured union jobs with public sector employers (located in other counties).

\section{Discussion}

In returning to the research setting in the summer of 2002, I wondered whether the same patterns of family stability and instability - in both family structure and economic resources - had continued. While generalizations cannot be made on the basis of 13 interviews, the tendencies seem clear. I found that middle-class life remained very stable. Middle-class families lived in the same homes (or upgraded their housing), experienced no household compositional changes, and principal breadwinners retained the same good employment. I again found greater family instability among households who had been working class or poor at the time of the initial research. Families who had been economically disadvantaged in the mid-1990s (lower-income working class and poor) were clearly more likely to have experienced family compositional changes and further economic dislocations than higher income families.

I did not find a sample of families of "just folks" with similar economic and family circumstances in this small rural community. Instead, the research uncovered considerable family diversity. Here I return to the subject of the contribution of feminism to understanding family diversity. Feminist family scholars have theorized the relationship between access to a stable resource base and the ability to maintain a stable nuclear family (Baca Zinn, 1994; Rapp, 1992/1978); Stacey, 1991). As Rayna Rapp wrote in her hallmark essay on feminism, family, and social class in 1978, "To achieve a normative family is something many categories of Americans are prevented from doing because of the ways that their households plug into tenuous resource bases" (p. 62). Simply stated, insecure economic resources - a characteristic of working-class and poor families - do not provide the foundation needed for the establishment and support of stable nuclear families. Instead, the uncertainties of day-to-day life require households of individuals with insecure resources to be flexible and 
adaptive as they adjust to ever-shifting circumstances (Stacey, 1991). In contrast, middle-class families enjoy the benefits of a secure resource base and usually have access to nonfamily institutions such as credit at banks, good medical coverage, and pension plans that see them through difficult times (Rapp, 1992). These scholars conclude that family diversity is produced by inequalities embedded in the structure of contemporary society.

In analyzing the 1995-1996 data, I found that middle-class families had been able to sustain a normative nuclear structure, while the marital bonds of poorer families had been more tenuous and temporary. Most poor or near-poor adults had lived in circumstances of economic uncertainty throughout their adult lives. These families had varying, but generally limited success at constructing family stability on an insecure material base. The stable resource base of middleclass families insulated them from the day-to-day economic strains and fullblown economic crises that increase hostility and negatively affect the partner relationship in less economically secure families (Conger et al., 1990; Gomel et al., 1998). The connection between "money trouble" and "family trouble" remains clear in the follow-up study.

Families continue to identify the same central issue of concern related to living in a rural county: the difficulty of earning a "decent living" in a low-wage labor market. Middle-class families are somewhat isolated from this concern, but working-class and poor individuals spoke extensively about the challenges they experienced and the strategies they used to support their families. This analysis highlights the economic vulnerability of the working class in rural America. Interviewees provided examples of what the literature tells us, that is, that rural women are especially disadvantaged (Gibbs, 2001). In-county service jobs available to women - hotel and nursing home housekeeping, retail, and restaurant work-paid between $\$ 5.25$ and $\$ 7.25$ an hour, with none providing health care benefits.

Several women have moved into cohabitation relationships. Three of four divorced women who have new residential relationships with men have cohabiting relationships. Cohabitation is a variable that is related to both family structure change and economic strategies. While the decision to cohabit is presumably made for relational reasons, it can also be seen as a household strategy. Cohabitation provides economies of scale and, perhaps more significantly, it also provides the opportunity to construct a two-income household. Whether or not cohabiting couples pool income, they typically share the bills. Thus cohabitation might be seen as a residential strategy that promotes economic well being for the individuals involved without the legal entanglements inherent in marriage. Cohabitation might be especially attractive to women in a 
personal context in which their prior marital experience proved to be neither permanent nor satisfying, and a community context in which few jobs have the potential to provide single mothers with an adequate standard of living.

A significant public policy debate currently surrounds the question of whether the promotion of marriage among poor single mothers should be funded by federal dollars as part of the TANF program. ${ }^{6}$ The assumption behind the policy initiative is that marriage will improve the economic status of poor women and their children. An analysis based on my initial data found that marriage had not brought economic well being to sample women on the economic margins (Wells \& Baca Zinn, 2004). Moreover, new data from the follow-up study show that the marriages of poor and near-poor women have been quite unstable. In circumstances of continuing economic hardship, the relationships of many couples in remarriages or unconventional first marriages have crumbled. Relevant here is Lichter, Graefe, and Brown's (2003) finding that poor mothers who marry and then divorce are actually worse off economically in the long term than if they had remained unmarried. Poverty-reduction is surely an important goal; however, a public policy that encourages marriage without attending to wage scales for less-skilled workers or providing services for working families will be limited in its ability to effect positive change.

\section{Conclusion}

In concluding this article, I return to a feminist theme identified above, that is, the importance of paying attention to women's perspectives, and I consider the policy implications of the issues they raise. The experiences of this sample of rural women point to the interrelationship between local labor-market conditions and family life. Many of the rural parents represented in this research struggled to survive on low-wage work or extended their workdays by commuting and/or working considerable overtime. In this setting as in other rural places, many families are stressed by the competing demands of work and family. Time and money pressures take a toll on family life. Anne Kennedy, a teacher and keen observer of the community, raises the question of the quality of life experienced by the families of many of her students. She says, "I don't know how they do it. People are working so much that family life suffers. Mom is gone so much." She reports that many children "hang around" after school because they have nowhere to go. Parents (who commute) are gone for extended hours, so students who stay for after-school functions may wait several hours for a parent to pick them up.

\footnotetext{
${ }^{6}$ A recent policy brief from the Center for Law and Social Policy (CLASP) provides a good summary of the research findings on this topic (Roberts, 2004).
} 
The family concerns of these research participants have implications for rural policy makers. Rural communities have failed to provide an infrastructure that allows parents both to work enough to support their families and to meet their children's day-to-day needs. Listening to the voices of the women who participated in this research suggests that services in support of commuting families are especially needed in this community. More generally, rural communities would benefit from more comprehensive transportation and childcare services for families. An advantage of providing services (over traditional economic development) is that services can be implemented that respond directly to perceived deficits in local community services and can be adapted to changing circumstances over time. Greater attention to the needs of working families would represent a major step toward creating truly "family-friendly" rural communities.

Finally, this research supports the contention that family diversity is here to stay. In this study of the families of a sample of White rural women, social class creates multiple contexts for family life. Middle-class families have secure employment and stable nuclear families. Working-class and poor families experience greater insecurity. Moving down from the highest paid working-class families to the poorest families, economic vulnerability and family instability increases. This pattern - identified in the initial research - continued in the follow-up study. Distinctive social-class divisions in this society predict that families will continue to be shaped in a multiplicity of ways. 


\section{References}

Baca Zinn, M. (1994). Feminist rethinking from racial-ethnic families. In M. Baca Zinn \& B.T. Dill (Eds.), Women of color in U.S. society (pp. 303-314). Philadelphia: Temple University Press.

Bokemeier, J. L. \& Garkovich, L. E. (1991). Meeting rural family needs. In C.B. Flora \& J.A. Christenson (Eds.), Rural policies for the 1990s (pp. 114-127). Boulder, CO: Westview Press.

Buttel, F. H., Browne, W. P., Christopherson, S., Davis, D., Ehrensaft, P., Freshwater, D., Gaventa, J., \& McMichael, P. (1993). The state, rural policy, and rural poverty. In Rural Sociological Society Task Force on Persistent Rural Poverty, Persistent poverty in rural America (pp. 292-326). Boulder, CO: Westview Press.

Catanzarite, L., \& Ortiz, V. (1996). Family matters, work matters? Poverty among women of color and white women. In D. Dujon \& A. Withorn (Eds.), For crying out loud: Women's poverty in the United States (pp. 121-139). Boston: South End Press.

Collins, R. (1988). Women and men in the class structure. Journal of Family Issues, 60, $27-50$.

Conger, R. D., Elder, Jr., G. H., Lorenz, F. O., Conger, K. J., Simons, R. L., Whitbeck, L. B., Huck S., \& Melby, J. N. (1990). Linking economic hardship to marital quality and instability. Journal of Marriage and the Family, 52, 643-656.

Economic Research Service. (2003). United States fact sheet. USDA/ERS. Retrieved from http://www.ers.usda.gov/ StateFacts/US.HTM

Edin, K., \& Lein, L. (1996). Work, welfare, and single mothers' economic survival strategies. American Sociological Review, 61, 253-266.

Egan, T. (2002, Dec. 8). Pastoral poverty: The seeds of decline. New York Times Sec. 4, p. 1.

Flora, C. (1992). The new poor in Midwestern farming communities. In C. M. Duncan (Ed.), Rural poverty in America (pp 201-211). New York: Auburn House.

Gaguin, D. A., \& DeBrandt, D. A. (2000). 2000 County and city extra: Annual metro, city and county data book 10th ed. Lanham, MD: Bernan Press.

Gibbs, R. (2001). Nonmetro labor markets in the era of welfare reform. Rural America, $16(3), 11-21$. 
Gomel, J. A., Tinsley, B. J., Parke, R. D., \& Clark, K. M. (1998). The effects of economic hardship on family relationships among African American, Latino, and Euro-American families. Journal of Family Issues, 19(4), 436-467.

Gringeri, C. E. (2001). The poverty of hard work: Multiple jobs and low wages in family economies of rural Utah households. Journal of Sociology and Social Welfare, 28, 322.

Higginbotham, E., \& Weber, L. (1992). Moving up with kin and community: Upward social mobility for black and white women. Gender \& Society, 6, 416-440.

Jencks, C. (1997). Foreword in K. Edin \& L. Lein, Making ends meet: How single mothers survive welfare and low wage work. New York: Russell Sage Foundation.

Lichter, D., Grafe, D., \& Brown, J. B. (2003). Is marriage a panacea? Union formation among economically disadvantaged unwed mothers. Social Problems, 50(1), 60-86.

Nelson, M. K., \& Smith, J. (1999). Working hard and making do: Surviving in small town America. Berkeley, CA: University of California Press.

Newman, K.S. (1993). Declining fortunes: The withering of the American dream. New York: Basic.

Rapp, R. (1992/1978). Family and class in contemporary America: Notes toward an understanding of ideology. In B. Thorne \& M. Yalom (eds.), Rethinking the family: Some feminist questions (pp. 49-70). Boston: Northeastern University Press.

Reinharz, S. (1992). Feminist methods in social research. New York: Oxford University Press.

Roberts, P. (2004). I can't give you anything but love: Would poor couples with children be better off economically if they married? (CLASP Policy Brief, Couples and Marriage Series No. 5) Available from http://www.clasp.org.

Rubin, L. B. (1994). Families on the fault line. New York: Harper Collins.

Stacey, J. (1991). Brave new families: Stories of domestic upheaval in late twentieth century America. New York: Basic.

Thorne, B. (1992). Feminism and the family: Two decades of thought. In B. Thorne \& M. Yalom (Eds.), Rethinking the family: Some feminist questions (pp. 3-30). Boston: Northeastern University Press.

Tickamyer, A., Bokemeier, J., Feldman, S., Harris, R., Jones, J. P., \& Wenk, D. (1993). Women and persistent rural poverty. In the Rural Sociological Society Task Force on Persistent Rural Poverty Report: Persistent poverty in rural America (pp. 200-229). 
Boulder, CO: Westview Press.

U.S. Census Bureau. (2001). Profiles of general demographic characteristics: 2000. Washington, DC. Table DP-1.

Wells, B. (1999). Family continuity and change in a restructured economy: A case study from rural Michigan. Ph.D. dissertation, Department of Sociology, Michigan State University.

Wells, B. (2002). Women's voices: Explaining poverty and plenty in a rural community. Rural Sociology, 67, 234-254.

Wells, B., \& Baca Zinn, M. (2004). The benefits of marriage reconsidered. Journal of Sociology and Social Welfare, 31(4), 59-80.

White, J. M., \& Klein, D. M. (2002). Family theories (2nd ed.). Thousand Oaks, CA: Sage.

Willits, F. K., \& Luloff, A. E. (1995). Urban residents' views of rurality and contacts with rural places. Rural Sociology, 60, 454-466.

Wilson, W. J. (1987). The truly disadvantaged. Chicago: University of Chicago Press.

Wright, E. O., Hachen, D., Costello, C., \& Sprague, J. (1982). The American class system. American Sociological Review, 47, 709-726. 